\title{
血圧反応性の穴進は将来の 高血圧発症を予測できるか?
}

\section{札幌医科大学心理学教室＼cjkstart澤田＼cjkstart幸展}

\section{Can augmented blood pressure reactivity predict future hypertension?}

\author{
Yukihiro SAWADA \\ Department of Psychology, Sapporo Medical University, \\ South 1 West 17, Chuo-ku, Sapporo, 060-0061, Japan
}

\begin{abstract}
Reactivity hypothesis states that subjects showing an augmented blood pressure reactivity to standardized mental stressor (pressor test) may be at risk of developing hypertension, and in its stronger form, that such hyperreactivity plays a causal role. In the present review, the hypothesis was revaluated, applying the concepts of reliability and validity of psychological tests to the pressor test. Assessment was done on intra-test, inter-test, and test-episode (lab-life) reliabilities, and on predictive validities in a broad (as a predictor) and a narrow (as a contributor) sense, as well as on concurrent validity in a broad sense (the test vs. family history of hypertension). Collectively, the pressor tests seemed to be, at most, moderately reliable and valid and consequently the content of reactivity hypothesis could not be fully affirmed.
\end{abstract}

Key words : reactivity hypothesis, blood pressure reactivity, hypertension, cardiovascular system, mental stress

【要 約】 反応性仮説の主張によれば, 標準化された精神的ストレッサー（昇圧テスト）に対して血圧反 応性に克進を認める個人は, 高血圧を発症する危険性がある, あるいは, いっそう強い主張として, そのよ らな過剒反応性は原因の一つをなす，といら．本評論では，心理テストに拈ける信頼性括よび妥当性の概 念を昇圧テストに適用して，この仮説が再評価された．テスト内，テスト間，执よび，テストーエピソード （実験室一日常生活）に扔ける信頼性，並びに，広義（予測因子として）扣よび狭義（寄与因子として）の 予測的妥当性，さらには，広義の併存的妥当性（テスト対高血圧家族歴）が，それぞれ評価された。総じ て, 昇圧テストはせいぜい中等度の信頼性と妥当性しか有して抢らず，乙たがって，反応性仮説の内容は 十分に肯定できるものとはいえなかった。 


\section{はじめに}

このところ，心理生理学の分野では心蔵血管系 の指標を扱った研究が急速に増えてきており, 脳 波関連の研究を凌駕する勢いである (Sanchez, Pedraja, Quiñones, \& Martinez, 1996). 心理生理 学の専門雑誌はもとより, 行動医学や心身医学さ らにはバイオフィードバック関連の雑誌を見て も，こうした種類の論文が $30 \%$ 40\%前後を占め ている，我が国の対応する雑誌の場合はまだ多い とは言えないが，それでも $15 \%$ 程度に達する。

その理由として，二つのことが考兄らょう。 第 1 に, ストレス性疾患を理解するに当たって, 神経症的葛藤のような仮説構成体とそこから推量 される特定の性格特性などの資料に依拠しがちな 心身医学的接近法よりは, 行動的・生理的に観測 可能なデータを拠り所とする行動医学的接近法が 重視されるよらになってきた。したがって，たと えば高血圧の発症過程を理解し治療法を組み立て るに当たっても，「抑圧された敵意」を主たる問 題とするのではなく, 各種の生物行動論的な要因 を考慮に入れたやり方が強調されるようになった のである (Manuck, Kasprowicz, \& Muldoon, 1990).第 2 にこうした接近法を方法論的に支亲 るものとして, 医用電子工学扣よびュンピュータ 技術の急速な発展により, 最近では血圧や心拍出 量, あるいは,「平均血圧/心拍出量」で換算され る末梢血管抵抗などの心臓血管系指標が，無侵襲 かつ連続的に測定できるようになっている。そこ で，たとえばストレス刺激負荷時の心拍数増加 減少を調べるといった従来のやり方だけでなく， 血圧上昇が心拍出量の増加によるのか末梢血管抵 抗の増加によるのかといら，血圧上昇とその血行 力学的機序までを視野に入れた詳細な分析が可能 となってきたことを挙げることができる（澤田， 1990).

こうした二つの理由から，たとえば実験室での ストレス刺激によって誘発される一過性の血圧上 昇についても, これを血行力学的視点から詳細に 分析するとともに, 将来の高血圧発症へどのよう につながり得るかを生物行動論的接近法に立って 考察する多数の研究が登場することとなった。そ の背後にあって多くの研究者を駆り立て, 論文数
を急膨張させている共通した信念のようなものこ そ, 以下でその是非を論じる反応性仮説に他なら ない，したがって，反応性仮説を吟味すること は，現在の心臓血管系心理生理学に括ける主要な 問題意識を理解する上できわめて重要と言えるで あろら。

ただし，反応性仮説をめぐる研究は，その論文 数がおびただしいだけでなく，問題意識のありよ らも多岐であるため，その全体的な動向を把握す るのが必ずしも容易ではない。そこで, 本評論で は，既存の知見を整頓するための枠組みとして， 心理テストに和ける信頼性および妥当性の概念を 適用し，反応性仮説の現状と問題点を明らかにし ようと試みた。

\section{反応性仮説}

先ず始めに，反応性扔よびこれに基づいた反応 性仮説の定義づけとかかわる事柄を整理して扣こ う.ここで, 過去の議論の大半は一過性の血圧上 昇対高血圧をめぐるものであることから，本評論 でも血圧反応性およびこれを指標とした反応性仮 説に絞って話を進めることとする。ちなみに，こ こで言う高血圧とは，慢性的な血圧上昇の直接的 な原因が特定でさないいわゆる本態性高血圧を指 すが, 大半の高血圧はこの類である.

さて, 血圧反応性とは, Matthews (1986)によ れば「特定の環境刺激に対して生じる, 対照值な いし統制值と比べた血圧值の逸脱を指す」。ある いは, Manuck et al. (1990)によれば「行動的ない し心理的な刺激にさらされたとき血圧に出現する 個人間変動性とかかわる」，両者に共通するのは， ストレス刺激負荷に対する血圧の反応を調べるこ とで, 安静時には見えにくい新たな情報を得よう とする点である。一方, 異なるのは, 他の個人の 反応性と比較した相対的位置づけを問題とするか 否かといら点である．後者については血圧反応性 の定量化に違いをもたらし得るから，ここで若干 触れておこう。実際, Matthews (1986)に従えば, 血圧反応性は単純に差値（＝ストレス刺激負荷時 血圧值一安静時血圧值) で表現できる。しかし， Manuck et al. (1990)の場合は, 安静時血圧值のス トレス刺激負荷時血圧值に対する回帰直線を実験 
に参加した全被験者のデータから求め, 安静時の 血圧值に対応する回帰直線上のストレス刺激負荷 時血圧予測值を得る。そして, 血圧反応性は, 残 差値（ニストレス負荷時血圧値一ストレス刺激負 荷時血圧予測值) で換算し直す。残差値に掞いて は被験者集団の標本特性が影響してくるものの， 差值の場合と異なり, 安静時血圧值の影響が除去 されるといら利点がある。

こうした，血圧反応性の定義を踏まえた上で， 反応性仮説の言わんとするところに話を進めよ 5. 問題の反応性仮説 (reactivity hypothesis) と は, Pickering \& Gerin (1990)によれば「血圧反応 性の元進は将来の高血圧発症にとって危険因子の 一つである」，あるいは「寄与因子の一つを成す」 と表現される。ちなみに, 前者で言ら危険因子に は, 予測因子と寄与因子の両方が含まれる。ここ で, 予測因子であるとは, 過剩な血圧反応性が将 来高血圧を発症させるのと同質な未知の第 3 因子 によって引き起こされていることを含意してい る。過唾な血圧反応性が高血圧の発症よりも時間 的に先行するため, あたかも予測力を持つように 見えるわけである.一方, 寄与因子であるとは， 血圧反応性の交進が将来の高血圧発症に何らかの 因果的かかわりを有するとの見方に立っている。 反応性仮説では, 血圧反応性の元進が将来の高血 圧発症にとって少なくとも予測因子，あるいは， もっと積極的に寄与因子であることを期待してい ると読み取れよう。

\section{昇圧テスト}

こうして, 血圧反応性並びに反応性仮説の意味 するものは素描し終えたが, 当の血圧反応性を誘 発する「特定の環境刺激」(Matthews, 1986)ない し「行動的ないし心理的な刺激」(Manuck et al., 1990)とはそもそもいかなるものであろらか．血 圧反応性は，当然ながらこうした刺激に対して誘 発されるものであるから, 次にはこちらの方を整 頓する必要があろら。それは実験室の統制された 状況下で負荷されるのが一般的であり, 本評論で 意図する心理テストとの対比を念頭に置けば，昇 圧テストと呼ぶのが適当と思われる。したがっ て, 昇圧テストの負荷で誘発される血圧反応性
は，心理テストを実施して得られるテスト得点に 相当しょう。ちなみ，日常生活場面で遭遇する 血圧上昇の引き金となる出来事は, 観察者の側か ら見れば意図的統制の効かないエピソードであ る。したがって, こちらは昇圧エピソードと呼ん で区別して执こう。な技，以下で昇圧テストにつ いて言及する事柄は多くの場合昇圧エピソードに も当てはまるから，必要がない限り昇圧テストに 絞って話を進める.

そこで，昇圧テストの具体像であるが，第 1 に，ストレス刺激のいわゆる精神的対身体的とい ら分類に従えば, 昇圧テストとしては前者の方が 適切であるように思われる。なぜなら，後者の典 型である自転車エルゴやトレッドミルといった等 張性運動は確かに一過性の血圧上昇を誘発する が，長期的に見ればむしろ血圧下降をもたらすも のであり, 軽症高血圧に対する非薬物療法として その有効性が確かめられつつある。晃生活での 昇圧エピソードは，その蓄積が有害な影響を及ぼ し得るものでなければ反応性仮説の文脈に乗りに くいから，その候補はどうしても精神的昇圧エピ ソードに限定されてこよう。したがって，その実 験室的模擬と見なされる昇圧テストも，こういっ た種類のものが主流となる。そこで，以下では， 昇圧テストと言えば主として精神的なものを指す ことにする。

第 2 に, 精神的昇圧テストとしては，さらに 2 種類の下位型が考兄られる。その中核となる行動 論的概念区分が，能動的対処対受動的対処である (Obrist, Gaebelin, Teller, Langer, Gringnolo, Light, \& McCubbin, 1978). ここで, 能動的対処と は, 競争や挑戦を求められ，あるいは評価を下さ れ, しばしば情動的混乱を伴うような場合の行動 様式を指す。一方, 受動的対処とは, 動きの取れ ないまま注目や監視を続けるとか, 有効な対処の 手だてが見つからないとか，遂にはなす術もなく ただ耐えるといった場合の行動様式を指す．能動 的対処を求められる典型が，たとえば暗算や電撃 回避反応時間などである (Allen \& Crowell, 1989). 一方, 受動的対処を余儀なくされる典型が寒冷昇 圧や騒音などである (Sawada, 1993)，各種の動物 実験で誘発されてきた Cannon 流の緊急反応ない 
し「闘争か一逃走か」反応は前者の強烈な場合で あり，いわゆる凍結反応は後者の極端であると見 なされよう。

これら 2 類型の昇圧テストは, 血行力学的昇圧 機序が対照的に異なることをその特徵とする。す なわち,「平均血圧＝心拍出量 $\times$ 末梢血管抵抗」 であり，血圧の上昇は心拍出量増加ないし末梢血 管抵抗増加によってもたらされるわけであるが， 能動的対処事態にあっては心拍出量の増加が血圧 上昇に効いてくる (Allen \& Crowell, 1989). これ に対し, 受動的対処事態では末梢血管抵抗の増加 が血圧上昇に寄与する (Sawada, 1993)。こうした 対照的な違いが生じるのは, 自律神経調節機能の 面にまで立ち返ってい齐ば，能動的対処事態では $\alpha$ 抢よび $\beta$ の両アドレナリン作動性交感神経活動 が交進するのに対し, 受動的対処事態では $\alpha$ アド レナリン作動性交感神経活動のみがえ進するため である ${ }^{1}$. 詳しくは他の論文に譲るが（澤田, 印刷 中)， $\alpha$ アドレナリン作動性の交感神経活動六進 は内臓および皮膚領域における血管収縮をもたら し， $\beta$ アドレナリン作動性のそれは心拍数の増加 や骨格筋での血管挔張をもたらす。その結果, 能 動的対処事態では，心拍数の増加から心拍出量増 加を来すが, 内臟・皮膚領域での血管収縮と骨格 筋での血管拡張が相殺し合うため, 末梢血管抵抗 はむしろ減少傾向を示す。一方, 受動的対処事態 では, 内蔵・皮膚領域での血管収縮が主として効 いてくるため, 未梢血管抵抗の増加が著しい.

これら 2 類型の昇圧テストは, 行動論的にみれ ば能動的対処型対受動的対処型, 血行力学的にみ れば心拍出量増加型対末梢血管抵抗増加型, そし て自律神経調節機能の面からみれば $\alpha \beta$ 型（ $\alpha$ と $\beta$ の双方が方進）対 $\alpha$ 型といった具合に，さまざ まな名称で呼ぶことが可能である。しかし，これ ら 3 側面の中で, 高血圧の発症過程とかかわって 病理生理学的にもっとも注目を浴びてきたのは交 感神経活動であることから (Abboud, 1982), 以下 では昇圧テストを $\alpha \beta$ 型対 $\alpha$ 型の 2 類型に区分し
て話を進めることにする。

さて, 反応性仮説の主張に戻って, 昇圧テスト を心理テストとの対比で吟味し直してみよう。容 易に気づくことであるが，昇圧テストではそれ自 体にとって外的な事柄である高血圧を推定するこ とに目的が置かれている。皇れも将来的に発現す る事柄が問題とされている。つまり, 昇圧テスト では, 心理テストでいら基準関連妥当性一それ も，予測的妥当性が問われているのである。ただ し, 昇圧テストから得られるテスト得点ともいら べき血圧反応性が，既述のような意味での予測因 子に過ぎないのであれば広義の予測的妥当性を, 一方, 寄与因子として働いているのであれば狭義 の予測的妥当性を有するとして，両者の水準を区 分けして括いた方がよいであろう。

もっとも，こらした議論が成り立つそもそもの 前提として心理テストで信頼性が問題とされるよ らに，昇圧テストにおいても同様な意味での信頼 性が問われることになる，加えて，心理テストが 一般的にそうであるように, 昇圧テストの信頼性 と妥当性を検討する場合でも, 前者よりは後者の 方がきわめて難問である.したがって, 本評論で も先ずは必要条件としての信頼性の議論から入る ことになる。この中に含まれるのは, 心理テスト でいえば再テスト法での評価に相当する同一昇圧 テスト間信頼性, 折半法での場合に匹敵する異種 昇圧テスト間信頼性, および, 後者の延長と見な される昇圧テスト（実験室）一昇圧エピソード （日常生活）間信頼性といら 3 領域の諸知見であ る. 次いで妥当性の問題を論じることになるが, 血圧反応性の克進が将来の高血圧発症に寄与因子 としてかかわると明言できるような, 狭義の予測 的妥当性を保証するデータは現在までのところ存 在しない，そこで，血圧反応性が将来の高血圧発 症に対する予測因子であるか否かを問う，広義の 予測的妥当性を扱らことにする。市た，両親の一 方または双方に高血圧の既往歴（高血圧家族歴） がある若年者に，血圧反応性の交進が認められる

1) 自律神経系の節後線維末端おける化学伝達物質は, 副交感神経系ではアセチルコリンであるが, 交感神経系では ノルアドレナリンが一般的である.アドレナリン作動性神経とは,ノルアドレナリンを放出する交感神経のことを 指すが，その作用を受ける臟器側の受容体は, 交感神経アミンに対する反応性の相違から, $\alpha$ との 2 種に大別さ れる.こうした受容体の相違に対応して,アドレナリン作動性神経も $\alpha$ そのの2種に区分して呼ばれる。 
か否かを問らことにする. 後者の接近法は, 心理 テストに拈基準関連妥当性とのかかわりでい えば, 昇圧テストの結果が外的基準である高血圧 家族歴（高血圧々れ自体ではないにしても）之同 時期に評価可能という点で, 広義の併存的妥当性 を吟味するものといえよう。こうして, 昇圧テス トの妥当性をめぐって, 本評論ではいずれも間接 的な 2 領域の諸知見を評価し，それでも不足する 部分は生物行動論的に見た高血圧発症の代表的な 作業仮説をいくつか紹介して補らこととする.以 上のよらな枠組みを設定した上で, 昇圧テストに 関する従来の諸知見を順次整頓し, 反応性仮説の 是非を論じて行くことにしょう。

\section{信頼性 \\ 同一昇圧テスト間信頼性}

心理テストになぞらえて言えば，同一昇圧テス ト間に拈ける信頼性とは, テストー再テスト信頼 性のことである。すなわち, 同一の昇圧テストを 同一被験者群にある期間を掞いて繰り返し実施し たときの，テスト間相関係数を表す。この問題を 扱った21の研究について, Manuck, Kamarck, Kasprowicz, \& Waldstein (1993)は詳細な検討を試 みている。それによると, 同一昇圧テスト間相関
係数の平均值は, 収縮期血圧で 0.51 , 拡張期血圧 で0.34であった，信頼性の值としてはさほど高く なく, 被験者数は少なく, 昇圧テスト再負荷まで の期間も短いなど，問題が残るという。ちなみ に, 本評論の視点から補足すれば, 昇圧テストと しては $\alpha \beta$ 型と $\alpha$ 型の双方が満遍なく用いられて きて扣り, 血圧反応性としては直観的理解が容易 であるためか, 残差值ではなく差值で求められて いる場合が大半である。な拉，血圧反応性の血行 力学的機序とかかわる心拍出量および末梢血管抵 抗の両反応性にまで踏み込んで信頼性を吟味した 研究は少ないが, 若干の関連データをまとめた Sherwood \& Turner (1992)によれば, 血圧反応性 とさほど変わらない 0.50 前後の值が得られてい る.ただし, 血行力学的昇圧機序のさらに背後を なす自律神経調節機能の六進・抑制については, いまだ調べられていよらである。

さて, 人格や知能などの心理テストと比べて, 昇圧テストではどうして中等度の信頼性しか得ら れないのであろらか。その理由の一つは，血圧反 応性に対する影響要因の多さである（Fig. 1; 昇圧 エピソードについても同様の影響要因を指摘でさ る)，血圧反応性は，それ自体が昇圧テストの型 ・強度・持続時間や反応性の換算方式による影響

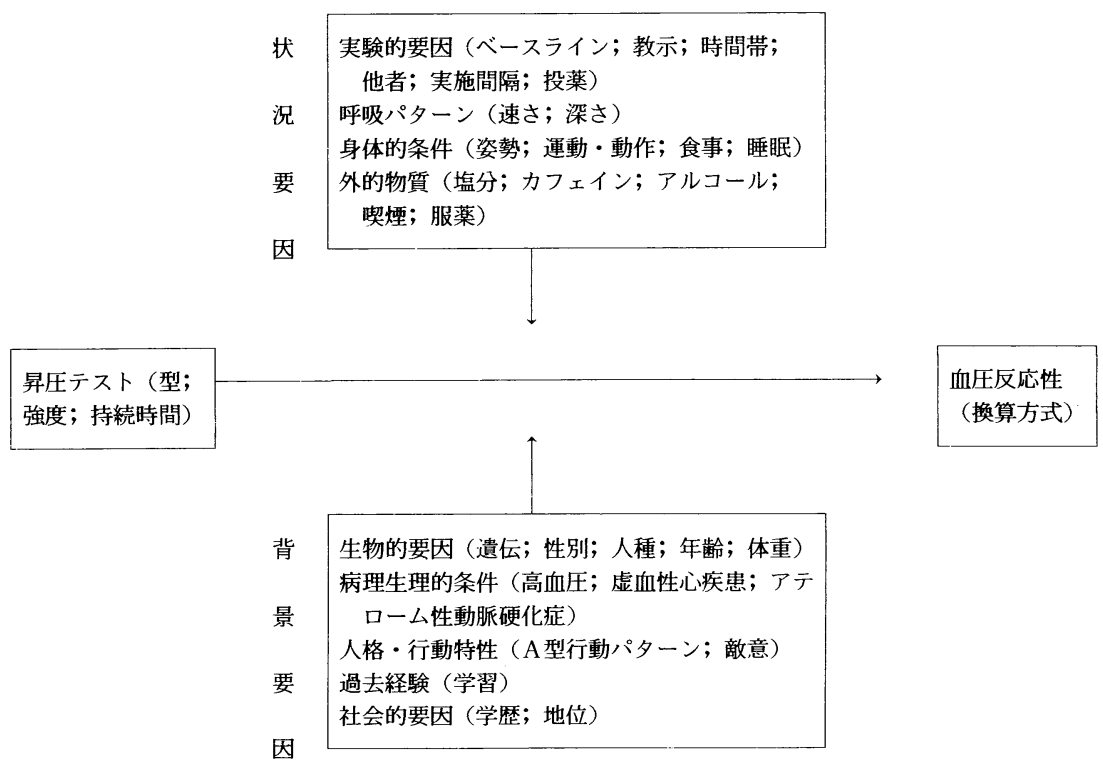

Fig. 1 血圧反応性に対する各種影響要因 
を受ける，加えて，実験当日ないしその前日から 数日前までに限られる状況要因（Fig. 1 上）と， 比較的長期に渡る背景要因（Fig. 1 下）が, 多数 影響を及ぼしている。

先ず, 状況要因の中で, 実験的要因に含まれる 「投薬」とは，たとえば昇圧テストの型を特定す

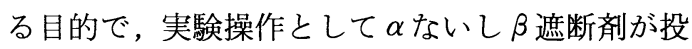
与された場合を指す。これに対し，外的物質に含 まれる「服薬」とは，被験者が日常用いている薬 物を指す。次に，実験的要因に挙げられている 「時間帯」とは，1日のどの時間帯で実験が行わ れたかを指し，日内リズムとの関連で無視できな いものである。また，身体的条件として挙げられ た「運動・動作」や「姿勢」とは, 昇圧テストを 負荷する直前の運動・動作や最中の姿勢（立位・ 座位・臥位) のことである.同じく，「食事」と は，テスト負荷のどれくらい前に食事を取ったか といらことであり，「睡眠」とは，テスト負荷前夜 の睡眠時間などのことである。一方, 背景要因に ついてはいずれも理解が容易であろう．ただし， 過去経験に「慣れ」が含まれていないのは，昇圧 テストに拈ける「持続時間」の項や, 状況要因中 の実験的要因に括ける「実施間隔」の項で取り扱 いが可能なためである.ちなみに, 状況要因中の 実験的要因に挙げられている「他者」とは，第三 者の同席とか，いわゆる白衣性高血圧の問題とも かかわる実験者バイアスなどといった幅広い影響 を指す．社会的要因ではあっても背景要因とは異 なるため,ここに挙げて扔いた。

次いで, いま一つ, 昇圧テストの信頼性が高ま りにくい理由がある。それは，心理テストに括け る項目数揖よび通過率との対比でいえば，負荷さ れる昇圧テストの種類があまりに少ないこと，並 びに, 誘発される血圧反応性に偏りが認められる ことである (Kamarck, Jennings, \& Manuck, 1993). 実際, 暗算のような強力な情動的混乱を惹 起する 1 種類だけを実施するのは, 昇圧テストと してはごく通常のやり方だが，心理テストにたと えれば反応傾向に偏りのある 1 項目だけで済ます のに似ている。この点に配虑した Kamarck et al. (1993) は, 心拍数の増加でいえば 5 拍〜 10 拍程度 の中等度に困難な, しかも, 情動喚起力が低くて
認知的ないし精神運動的要素の強い複数の昇圧テ ストを選別し，テスト全体として見たときの信頼 性を高めることに成功している。このように，適 切な昇圧テスト・バッテリーを組むやり方は，信 頼性を高める一つの重要な鍵となるかも知れな い.

\section{異種昇圧テスト間信頼性}

異種昇圧テスト間に招ける信頼性とは，異なる 昇圧テストを同一被験者群で同時期に実施したと きの, テスト間相関係数を表す。異種昇圧テスト の全体は上述の昇圧テスト・バッテリーに相当す るから, 下位 (異種) テスト間で相関係数を求め るやり方は，心理テストになぞらえれば折半法に よる信頼性の評価に相当しょう，あるいは，もっ と一般的に言光ば，バッテリーに含まれる各昇圧 テストは特性としての血圧反応性を相互に矛盾な く誘発できることが望ましいわけであり，心理テ ストでいう内的整合性が検討されていることにな ろら.

異種昇圧テスト間の信頼性は, 同一昇圧テスト 間ほど詳しく調べられているわけではない。そこ で，いくつかの例を挙げるにとどめる。たとえ ば, Turner, Sherwood, \& Light (1990)は, 暗算, 反応時間，スピーチといら 3 種の昇圧テストにつ いて相互の相関を調べた。その結果, 相互相関の 平均は収縮期血圧で 0.60 , 拡張期血圧で $0.43 て ゙$ あった。また, Gramer \& Huber (1993)は，暗算 対スピーチ準備の間で相関を求め, 収縮期血圧で 0.44 , 拡張期血圧で 0.26 の值を得た。さらに, Kamarck, Jennings, Geile, \& Manuck (1994)は, 視覚的短期記憶, 射撃ゲーム, 精神運動, スト ループ色名呼称の 4 課題を用い, 収縮期血圧で平 均 0.50 , 拡張期血圧で平均 0.45 の相互相関を得 た。これらの值を見る限り, 同一昇圧テスト間で の信頼性とさほど違わない中等度の水準であるこ とが分かる。

ここで，用いられた昇圧テストの型であるが， Turner et al. (1990)を別にすれば, 心拍出量や末 梢血管抵抗が同時測定されていないため, 判断は 必ずしも容易でない，それでも，心拍数の変化な どから推論するなら, Turner et al. (1990)や Gramer \& Huber (1993) で用いられた昇圧テスト 
はいずれも $\alpha \beta$ 型と考光られる。これに対し， Kamarck et al. (1994)の昇圧テストでは, 精神運 動が $\alpha \beta$ 型, 視覚的短期記憶, 射撃ゲーム, スト ループ色名呼称の 3 テストが $\alpha$ 型であろうと思わ れる。したがって，さまざまな昇圧テストについ て，その型にかかわらず中等度の相互相関が得ら れたわけであり，異種テスト間に拈けるある程度 の内的整合性を印象づ兴るのである，昇圧テス トは $\alpha$ 型であれ $\alpha \beta$ 型であれ， $\alpha$ アドレナリン作 動性の交感神経活動を一定程度六進させるといら 共通項を有するから (Allen, Boquet, \& Shelley, 1991; van Doornen \& van Blokland, 1992), これ ら異種テスト間に中等度の相互相関が認められ， 内的整合性が確保されるのであろう。ちなみに， 心拍出量および末梢血管抵抗の双方に関する反応 性の同時測定結果から (Turner et al., 1990), 異種 昇圧テスト間に括けるこれら指標の相関は前者で 平均 0.57 , 後者で平均 0.60 であり, 血圧反応性の 場合以上に高く出る傾向が認められる。ただし， ここでも， $\alpha$ 対 $\beta$ アドレナリン作動性交感神経活 動亢進とかかわる異種昇圧テスト間の信頼性は, いまだ調べられていないよらである。

\section{昇圧テストー昇圧エピソード間信頼性}

昇圧テストー昇圧エピソード間信頼性は，概念 的には異種昇圧テスト間信頼性の拡張と見なし得 るもので, 測定の場面に注目して実験室一日常生 活関連性と呼ばれることが多い。ただし，前者は 後者の単なる拡張とは見なし難い, 重要な意味合 いを持っている，といらのも，昇圧テストが狭義 の予測的妥当性を持つと期待する立場では, 当然 のことながら日常の昇圧エピソードが高血圧の発 症に寄与すると考える。したがって, 実験室で負 荷される昇圧テストでの血圧反応性は, 日常の昇 圧エピソードに抢けるとれを反映しなければ意味 を失らからである。こうしたきわめて重要な位置 づけがあるにもかかわらず，無侵襲なアンビュラ トリ（携帯式）血圧測定装置が普及し始めた最近 まで,この問題は本格的に検討することが難し かった。

さて, 昇圧テストー昇圧エピソード間信頼性 は, 文字通り考えると, 昇圧テスト执よび昇圧エ ピソードそれぞれの反応性から両者の相関を計算
して求められよう.ところが, 昇圧エピソードに ついては，行動日誌をつけたとしてもその特定が 必ずしも容易でなく，ベースラインをどこに取る かも判然としない. 加えて, 姿勢・動作・運動と いった身体的要因は (Fig. 1 参照), アンビュラト リ血圧測定の場合，データをばらつかせる最大の ものであり (Gellman, Spitzer, Ironson, Llabre, Saab, Pasin, Weidler, \& Schneiderman, 1990), 昇 圧ェピソードにしばしば重冨してくる。これら身 体的要因の影響は，たとえば身体各部位に装着し た角度センサーなどを用いてもある程度しか推定 できないから，日常生活場面で精神的な昇圧ェピ ソードの反応性を定量化するのは決して容易なこ とではない，そこで，昇圧ェピソードの反応性そ れ自体を求めるのではなく, アンビュラトリ測定 の特定期間に抢ける血圧時系列データの変動性 （たとえば標準偏差）を計算してこれに代えると いった方法がしばしば採られる。あるいは，反応 性の考方方から離れ，測定期間に和ける平均血圧 水準だけを問題とする場合もある。対応して, 実 験室の昇圧テストに関しても，血圧反応性のみな らずベースラインや昇圧テスト負荷時の平均水準 がしばしば検討の対象となる。な㧧, 日常場面で のアンビュラトリ血圧測定は, 仕事中対自宅時な いし日中対睡眠時で，それぞれ分割して取り扱う ことも往々にしてある.こうしたさまざまな幅が あり得る中で, そのあらゆる可能な組み合わせに ついて, 昇圧テストー昇圧エピソード間信頼性は 検討が試みられてきた。

Turner, Ward, Gellman, Johnston, Light, \& van Doornen (1994)は, 血圧反応性とその関連 指標全体を視野に入れた各種の昇圧テストー昇圧 エピソード間信頼性について, 32の研究を評論し ている、それによると，もっとも高い相関が得ら れるのは実験室での昇圧テスト負荷時血圧水準対 日常生活に拈ける平均血圧水準であって, しばし ば0.6-0.7に達する。これと比べれば, 昇圧テス 卜負荷時血圧反応性と日常生活時血圧変動性を始 めとする反応性関連の肝心の相関値は, せいぜい 中等度にとどまる。Turner et al. (1994)によれ ば，こうした結果になった理由として，第 1 に， アンビュラトリ血圧測定の頻度が日常生活におけ 
る血圧変動性の把握に影響していると考えられ る、実際，直接法によって日常場面での血圧を連 続記録し，そこから求められた変動性を実験室で の血圧反応性と対応させると，相関は高まること が知られている，第 2 ，覚醒中のすべてが当の 本人にとってストレスなわけではない。したがっ て，自宅にしろ仕事場にしろ，ストレスを体験し ているときの血圧を測定しなければ，実験室にお ける血圧反応性などの指標とはさほど高い相関が 期待できない。

ところで，既に吟味してきた同一昇圧テスト間 信頼性抢よび異種昇圧テスト間信頼性と比べれ ば，昇圧テストー昇圧エピソード間信頼性に影響 する要因はいっそら多いと予想される（Fig. 1参 照).したがって，実際の相関は前 2 者とさほど 異ならないものの，かりにこれらほどの相関が得 られなくても何ら不思議はない。とくに, 姿勢・ 動作・運動といった身体的要因は，上述のごとく 血圧の日内変動の大部分を規定するから, かりに 昇圧テスト負荷時血圧反応性と日常生活時血圧変 動性の相関がきわめて高く出たりすれば，昇圧テ ストは何ら精神的な要素を含まないことになっ て，かえって矛盾を生じさえする(Pickering \& Gerin, 1992). したがって, 逆に姿勢・動作・ 運動といった重畳部分をらまく除去できれば, 昇 圧エピソードの真の影響力が姿を現すとも期待で きる (Johnston, Anastasiades, Vögele, Clark, Kitson, \& Steptoe, 1992).

ただし，姿勢一つにしても，細心の注意が必要 である、たとえば, Turner \& Sherwood (1991) は，同一被験者に暗算を座位と立位で行わせた場 合，血圧反応性に関するこれらの間の相関係数は 相当低くなることを示した. 座位の暗算では $\beta$ ア ドレナリン作動性の交感神経活動方進がそのまま 出現するのに対し，立位の暗算ではこれに静水圧 による反射が加わるため, 思わぬ差が生じたので あろう。しかし，考元てみれば，実験室での昇圧 テストは座位を標準とするのに，日常生活の昇圧 エピソードは座位と立位と臥位を問わずさまざま な姿勢で出現する。したがって，姿勢による影響 部分を除去して昇圧テストと昇圧ェピソードの相 関を求めたとしても, 両者に㨟ける血行力学的昇
圧機序は異なる可能性があるため, 高い值が得ら れるとは保証し切れないのである。

もっとも, 血圧反応性の水準では駄目であって も, 心拍出量や末梢血管抵抗の水準で反応性を評 価すれば，座位対立位の暗算には中等度の相関が 認められるという(Sherwood \& Turner, 1993). こ れらの方が交感神経活動のいかんをいっそう強く 反映するため, 姿勢の違いによる静水圧的反射が さほど効いてこないのであろらと推測されてい る. 実験室と日常生活の双方において, 血圧だけ でなく，心拍出量と末梢血管抵抗についても測定 の必要が痛感されるところである（澤田・山越, 1995).さらには, これら血行力学的昇圧機序の 背後をなす $\alpha$ 対 $\beta$ アドレナリン作動性交感神経活 動の京進についても, 昇圧テストー昇厈ェピソー ド間信頼性を調べることが望まれる。

\section{妥当性 \\ 広義の予測的妥当性}

既述のごとく，広義の予測的妥当性に関する議 論では, 昇圧テスト得点ともいらべき血圧反応性 が, 将来の高血圧発症に対して少なくと予測因子 であり得るか否かを問題とする。この議論に見通 しが立たないようだと, 寄与因子としての可能性 を論じる狭義の予測的妥当性に踏み込む余地はな くなるし，また，上述のような昇圧テスト一昇圧 エピソード間信頼性を検討してみても, 反応性仮 説の立場からは意味がなくなる。

そこで, 広義の予測的妥当性を検討すべく, 歳 月をかけた疫学的な縦断研究がいくつか実施され てきた。たとえば, Pickering \& Gerin (1992)は， 寒冷昇圧, 運動, 暗算の 3 種について, 過去に得 られた代表的なデータをまとめている。それによ ると,もっとも伝統的な寒冷昇圧では，7研究中 の 5 研究で予測力から見た結果は明らかに否定的 であった。また，肯定的な二つについても，手続 きやデータ処理法に問題を認めた。一方, トッレ ドミルや自転車エルゴといった等張性運動におい ては, 8 研究中の 7 研究で 3 年から 32 年後の血圧 水準を予測できた。そして，いまだ蓄積の少ない 暗算では, 追跡期間が短いとはいえ 3 研究中の 2 研究で肯定的な結果が得られた。 
こうした，不一致な結果から示唆されるのは， とくに身体的昇圧テストである等張性運動とかか わって次の二つの事柄である．第 1 に，身体的昇 圧テストでは，すべての研究において血圧反応性 そのものよりもテスト時の血圧水準が指標とされ ている.したがって，その驚くべさ好結果は， ベースラインと反応性の合わさった血圧データか ら将来の血圧水準を予測したためであったのかも 知れない。これは, 昇圧テストー昇圧ェピソード 信頼性のところで触れた現象と質的に類似する。 実際, 日常生活での平均血圧水準ともっとも相関 が高いのは，実験室の昇圧テストに対する血圧反 応性ではなく，テスト負荷中の血圧水準であっ た。こうして, ベースラインと独立した情報を得 るべく反応性が求められて来たにもかかわらず， 予測力の面からすると反応性はベースラインに劣 る可能性が高いのである (Julius \& Schork, 1978). この点を補足する大変印象的な研究として， Thomas \& Duszynski (1982)によれば, ベースラ イン時の收縮期血圧が $125 \mathrm{mmHg}$ 以上である,な いし，高血圧家族歴があるような場合，ともに高 血圧発症の予測に有効であり, 両者が重なると顕 著な発症率と結びついたが，寒冷昇圧に対する血 圧反応性それ自体は何らの予測力も持たなかった といら。

第 2 に示唆されるのは, 等張性運動が文字通り 身体的昇圧テストであるのに対し, 暗算や寒冷昇 圧は本評論で主として取り上げてきた精神的昇圧 テストであり, したがって, 後者は前者に比べて 予測力が劣るといら可能性である。ここで, 精神 的対身体的昇圧テストの優劣を論じるに当たり，

3 研究中の 2 研究で肯定的な結果が得られた上述 の暗算について, その予測力を若干議論して扣こ う. 肯定的な結果とされた 2 研究のうち, Falkner, Kushner, Onesti, \& Angelakos (1981) は，十代の若年男女で，収縮期血圧ないし抎張期 血圧が90-95パーセンタイル順位に位置する者と 90 パーセンタイル順位未満の者を, 最大 41 力月ま で追跡調査した。 その結果, 前者の半数以上は, この期間に95パーセンタイル順位を越えてさらに 上昇を示した。これ自体はべースラインの予測力 を再確認させるものであるが，同時に，暗算時の
血圧反応性も前者で有意に大きいことが判明し た。 もっとも，暗算時に血圧反応性の高かった者 が，90-95パーセンタイル順位の者と完全な一致 を示すわけではない，そして，若年被験者群の 90 -95パーセンタイル順位抢よび95パーセンタイル 順位以上にある者を，それぞれ一般成人の境界域 高血圧および高血圧と対応させることに疑問が残 りはする。次いで, Borghi, Costa, Boschi, Mussi, \& Ambrosioni (1986)は, 境界域高血厈患者 のリンパ球内ナトリウム・イオン濃度を指標と し, その後 5 年間追跡した結果, この濃度が高い 者からしか慢性高血厈への移行は認められなかっ た。合わせて, この濃度が高い者では暗算に対す る拡張期血厈の反応性が大きく, 回復期の戻りも 悪かった.ただし, Falkner et al. (1981) と同じ く, 挔張期血圧反応性の大さい者がリンパ球内ナ トリウム・イオン濃度の高い者と完全に一致する わけでない。 むしろ, 拡張期血圧の反応性が回復 期の戻りょりも, 予測力の点で劣ることは問題で ある。しかも, Borghi et al. (1986)の用いた境界 域高血圧患者の大半は, 高血圧家族歴の持ち主で もあった。

こらして見ると，暗算のような比較的好結果の 得られた精神的昇圧テストについてさえ, 現段階 で広義の予測的妥当性が確認できたとは言い難 い、その証拠に, Falkner et al. (1981)の場合は ベースラインが, また, Borghi et al. (1986)の場 合はリンパ球内ナトリウム・イオン濃度が, それ ぞれもっとも予測力の高い指標であった。しか し，それでは身体的昇圧テストの方が予測力に優 れているかと言えば，そう簡単には断定できな い. 何故なら, 運動時の血圧反応性は調べられて いないからである。精神的昇圧テストと比べれ ば, Fig. 1 の背景要因の中でも, 人格・行動特性 や過去経験ないし社会的要因が効きにくい分だ け，どの被験者にとっても一様な負荷となりやす いが，これが好材料とも断言できないであろう。 そして，かりに身体的昇圧テストの方が予測力に 優れていたとしても，既述のような運動療法によ る血圧下降の可能性を考光るなら，反応性仮説の 是非を検討するテストとして最適とはいえないで あろう。身体的昇圧テストは，予測因子としての 
可能性を検討する広義の予測的妥当性とかかわっ て，その威力を発揮できるに過ぎないからであ る.

\section{広義の併存的妥当性}

昇圧テスト得点ともいらべき血圧反応性が, 高 血圧それ自体ではないにしても，やはり外的基準 である高血圧家族歴之同時期に検討されるとき， 心理テストになぞらえれば，基準関連妥当性の一 つである併存的妥当性が広義にみて評価されてい る。ここで，高血圧家族歴とは，ときに祖父母ま で含めることもあるが, 原則として両親の一方ま たは双方に高血圧の既往歴があることをいう。そ して，高血圧家族歴が外的基準であるとは，こう した生物的要因としての遺伝が (Fig. 1 参照) 将 来の高血圧発症にとって重要な予測因子であり, 恐らくは寄与因子であり得ることによる。実際, Stamler, Stamler, Riedlinger, Algera, \& Roberts (1979)によれば，高血圧家族歴のある若年者はそ らでない若年者と比べ 2 倍も高血圧になりやすい といら。

ここで，高血圧家族歴のある若年者をそうでな い若年者と比較することには，独自な利点があ る. 周知のごとく，血圧の慢性的な上昇は心臓と 血管の構造的変化を引き起し，これが 2 次的に系 の反応を変質させる。したがって，心蔵血管系の 機能を高血圧対正常血圧で比較しても，その差か ら高血圧発症の手がかりが得られるかは疑問な点 が多い，その意味で，血圧反応性のいかんを高血 圧の有無と対比させる狭義の併存的妥当性は, 反 応性仮説とのかかわりで見る限り, 重要な検討対 象とはなりにくい，むしろ，いまだ高血圧の発症 していない段階で, 将来へ向けた何らかの兆候を 探した方がよいのであり，高血圧家族歴のある若 年者が大いに興味をそそられるのである。ここで の期待は，高血厈家族歴のある若年者がそうでな い若年者と比べ, 昇圧テストに対する血圧反応性 で顕しいえ進を示すといらことである.

この点の当否はさまざまな研究者によって評論 されているが, 血圧反応性のみならず, 細胞にお
けるナトリウム輸送機序, 塩分摂取・血管内容量 ・腎機能, 心臓血管系の形態扣よび機能という諸 側面まで含めて 150 以上の研究を総合的に検討し た Muldoon, Terrell, Bunker, \& Manuck (1993)の まとめは, 多くの示唆に富んでいる。それによれ ば, 高血圧家族歴のある者は左心室に相対的な肥 大を認め, 前腕血管では薬物静注などに対する挔 張能力が低く，しかもその反応は過剰である。こ れらはもっとも顕著な特徵であるが, 次いで, 高 血圧家族歴のある者ではナトリウムーリチウム対 向輸送 ${ }^{2)}$ 上昇して和り, 腎血管反応性が方進し て拉り，塩分負荷によってもレニンーアンジオテ ンシン系ホルモンは修飾を受けない。そして，こ れら第 2 群と同程度の確からしさで, 高血圧家族 歴のある者は,トレッドミルや自転車エルゴなど の身体的昇圧テストに対し高い血圧反応性を認め る。これに対し, 暗算や寒冷昇圧といった精神的 昇圧テストでの結果は必ずしも思わしくなく，第 2 群の水準には達しない. 実際, 精神的昇圧テス トに拈いて，肯定的と見なされる結果は $30 \%$ 前後 の研究でしか認められず, しかも最新の精緻な研 究に拈いて結果はしばしば否定的である。

Muldoon et al. (1993)によれば，血圧反応性に限 らず, 各種の指標で結果が思わしくない理由とし て次の二つが挙げられるといら，すなわち，第 1 に, 被験者の抽出方法に問題がある。高血圧家 族歷は, 多くの場合被験者本人の自己申告に よって確認されて抢り，両親ないし祖父母の血 圧を何らかの方法でチェックできていない。ま た，両親と祖父母の 2 代にまたがる強い高血圧家 族歴の持ち主を被験者として抽出している研究 は，かなり少数である。な拉，これらと関連し て, Saab \& Schneiderman (1993)によれば, 被験 者たり得るのは主として若年正常血圧者であるか ら，その両親はいまだ若く，体質遺伝があっても 発現していない可能性がある。したがって, 被験 者の中には，高血圧家族歴があってもこれのない 方へ割り当てられる者があり得る。第 2 に，高血 圧は不均質な症候群であり，したがって，高血圧

2) 平滑筋および腎細動脈などの細胞に执いて, その成長・収縮力・ナトリウム恒常性に影響を与えるところの,ナ トリウムー水素交換系を反映する可能性がある. 
家族歴の意味する内容も被験者によって異なって くる可能性がある。これを逆に言らなら，精神的 昇圧テストに対する血圧反応性を調べる場合な ぞ，両親の一方または双方がいわゆる hyperkinetic ${ }^{3)}$ な境界域高血圧 (Julius, Weder, \& Egan, 1983) であるケースを抽出した方がよいのかも知 れない。こうした問題が解消できれば, 反応性仮 説を含めた各種の高血圧研究にとって, 高血圧家 族歴が相変わらず重要な研究領域であることは論 を待たないであろら。

\section{狭義の予測的妥当性}

既述のごとく，血圧反応性の妄進が将来の高血 圧発症に寄与因子としてかかわると明言でさるよ らな, 狭義の予測的妥当性を保証するデータは現 在までのところ存在しない。したがって，ここで は生物行動的論的に見た高血圧発症の代表的な作 業仮説をいくつか紹介して補うこととする。その 際, 発症過程のいかんにかかわらず，慢性の高血 圧に共通するのは末梢血管抵抗の増加による血圧 上昇であるから，作業仮説がここで終結すること に変わりはない。

こうした意図から，大きくは次の二つの仮説が 提唱されてきた。一つは，Guyton (1980)による自 動調節の概念を血圧反応性の充進と結びつけよう とする, Obrist (1983)の立場である. そこで, 基 となる自動調節であるが，Guyton (1980)によれ ば，将来高血圧を発症する者は遺伝的に腎臓での ナトリウム排泄能に異常がある。長期的にはこれ がナトリウムの体内貯留, 細胞外液量・循環血漿 量の増加を引き起し, 心拍出量の増加をもたら す.そのため, 末梢側では組織や臓器の血流量が 代謝欲求を越えて増加し，いわゆる過剰灌流状態 に陥る。これを解消すべく，それぞれの血管床は 抵抗血管を収縮させて血流量を落とそうとするか ら (自動調節)，結果的に末梢血管抵抗は増加す ることとなる。こうして，慢性の高血圧へ移行す るといら。さて，これを援用した Obrist (1983) は, 腎臓の先天的な異常の代わりに, $\alpha \beta$ 型の昇 圧エピソードを問題とし, 心拍出量増加による血
圧反応性の亢進に焦点を当てた，そして，この種 の昇圧エピソードを日常生活でしばしば体験する らちに, 高血圧の発症へ結びつくと主張した。こ らして, Guyton (1980)による自動調節仮説, 対す る, Obrist (1983)によるその行動論的変形は,「腎 ナトリウム排泄能の異常」対する「 $\alpha \beta$ 型昇圧エ ピソードに括ける $\beta$ アドレナリン作動性の交感神 経活動六進」をそれぞれの出発点とし，その後は

「心拍出量増加による血圧上昇—末梢の組織・ 臓器に打ける過剰灌流—自動調節—末梢血管 抵抗増加による血圧上昇」といら共通の発症過程 をたどる。しかし，これらの仮説の問題は，いず れの経過をたどるにしろ, 末梢の組織・蔵器に招 ける過剩灌流を通過しなければならないといら点 である.確かに，心拍出量増加を中心としたいわ ゆる hyperkinetic な境界域高血圧患者 (Julius et al., 1983) は，慢性の高血圧へ移行する確率もきわ めて高いことが知られている (Lund-Johansen, 1983). その意味では, 血行力学的な昇圧機序が心 拍出量増加から末梢血管抵抗増加へ移行する, Guyton (1980)ないしObrist (1983)の主張に合致し そうな患者群である。しかし，この種の患者で は, 心拍出量増加が血漿量増加に伴われておら ず，また安静時の酸素掑取量も増加傾向にあるた め, 末梢の組織・臓器で過剰灌流が生じていると は見なし難い。むしろ, hyperkinetic な症状を作 り出している本体は, 心蔵に拉ける $\beta$ アドレナリ ン作動性の交感神経活動六進と迷走神経活動抑制 である(Julius et al., 1983).しかも，境界域高血圧 全体の中でこらした症状を呈する者は，約30\%を 占めるに過ぎない(Julius, Pascual, \& London, 1971).したがって, hyperkineticな境界域高血厌 は，一部にしか見出されない点を別にしても，血 漿量正常かつ過剰灌流不在のゆえに Guyton (1980)の自動調節仮説に合致しない。それだけで なく， $\beta$ アドレナリン作動性の交感神経活動元進 といら点では当てはまるところがあるものの, や はり過剰灌流不在のゆえに Obrist (1983)の行動論 的変形とも食い違ってくる.

3) 本態性高血圧のらち, 若年性高血圧や境界域高血圧の一部に, 動悸・頻脈・発汗など, $\beta$ アドレナリン作動性交 感神経活動の亢進を呈するものがある。このような症状を hyperkinetic state（過動心状態）と称する。 
さて, 血圧反応性の妄進と高血圧の発症を結び つ牧るい一つの作業仮説は, Folkow (1978)に よるもので, 構造的適応仮説と呼ばれる. その発 症過程は,「昇圧エピソードに対する交感神経活

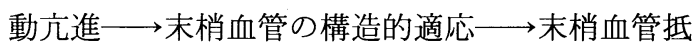
抗増加による血圧上昇」と推論されている。ここ で, 末梢血管の構造的適応とは次のようなことを 指す。すなわち, 抵抗血管は交感神経活動の克進 に際し, 管壁の厚さと内腔の比を増加させること で収縮するが，これが度重なると血管平滑筋の肥 厚をもたらすに至る。あたかも, ウェート・ト レーニングによる刺激の繰り返しが骨格筋の成長 をもたらすように, 昇圧エピソードの繰り返しは 血管平滑筋の成長を促するといったイメージが考 えられるかも知れない(Sherwood \& Turner, 1992).こうした意味での構造的適応である. そし て，いったん構造的適応が成立すると，わずかな 昇圧エピソードに対しても末梢血管は過敏な反応 を示すようになり, 慢性の末梢血管抵抗増加へ向 けた悪循環が始まる。

この Folkow（1978）の作業仮説は, 既述の Guyton (1980) による自動調節仮説や Obrist (1983)によるその行動論的変形と, 結合させるこ とも可能である. 事実, 「心拍出量増加による血 圧上昇—末梢の組織・臓器に括ける過㮃灌流 $\longrightarrow$ 自動調節」といら発症過程の重要な 1 段階 は，そっくりそのまま「心拍出量増加による血圧 上昇一末梢血管の構造的適応」之置き換えるこ とが可能である。こうすれば，過剰灌流をめぐる 論争は避けて通ることができよう。だが，Folkow (1978)の作業仮説に括ける問題は, 構造的適応成 立後の早い時期である境界域高血圧の段階から認 められるといわれる, 未梢血管の昇圧エピソード に対する過敏さが必ずしも実証されていない点で あろら。ちなみに, Folkow 自身は， $\alpha \beta$ 型の昇圧 エピソードに注目していることから (Folkow, 1987), やはり $\beta$ アドレナリン作動性の交感神経 活動え進を念頭に置いているものと思われる。

な抒，以上に述べた二つの主要な作業仮説以外 にもいくつかのものが提示されているので, その 内の二つを補足的に言及して括こう．その第 1 は, Guyton (1980)をやはり基礎としながら，しか
し Obrist (1983) とは力点の置き所を変えた主張で ある.すなわち, Light, Koepke, Obrist, \& Willis (1983)は，「 $\alpha \beta$ 型昇圧エピソードに随伴する $\beta$ ア ドレナリン作動性の交感神経活動元進 $\longrightarrow$ 腎での ナトリウム拉よび水分の貯留—末梢血管抵抗増 加による血圧上昇」といら発症過程を想定してい る。ここで，昇圧ェピソードに見舞われたとき， 腎臓はいっそう迅速かつ効果的に過剩な塩分 ・水分を排泄して体液量を低下させ, 結果的に 心拍出量を減少させて血圧を下げょうとする のが普通である。しかし，たとえば $\alpha \beta$ 型昇圧 テストに対して心拍数反応性の交進を認めるヒト 被験者で(Light et al., 1983), あるいは同類の昇圧 テストである電撃回避を訓練されたイヌに括いて (Gringnolo, Koepke, \& Obrist, 1982), 血圧上昇と ともに腎臓でナトリウム抢よび水分に貯留の生じ ることが報告されている．腎機能はレニン分泌や ナトリウム・水分の再吸収に関してそれぞれ $\beta$ お よび $\alpha$ アドレナリン作動性交感神経活動の修飾を 受けるから，これらの充進によると思われるナト リウム・水分の貯留現象は, Guyton (1980)とは別 な意味での腎ナトリウム排泄能の異常と見なされ よう.

さて, 補足の第 2 はJulius et al. (1983)によるも ので, hyperkinetic な境界域高血圧を調べた結果 から，ある種の人格特性を高血圧発症の出発点に 置いている。すなわち, 彼らによれば, 外界へと 向から指向性が強く, しかし疑い深くて敵意を秘 め，らっ積した怒りを持つ個人では，その葛藤傾 向の強い行動が災いして中枢に抢ける慢性的な高 覚醒状態に陥る。そこで，「この種の人格特性 $\longrightarrow$ 中枢神経系の高覚醒状態—中枢神経系によ る自律神経系を介した心臓血管系調節の乱れ, と くに， $\beta$ アドレナリン作動性の交感神経活動光進 $\longrightarrow$ 心拍出量増加による血圧上昇—心臓に打将 る $\beta$ アドレナリン作動性受容体の調節低下, 心筋 構造の変化, 抢よび, 末梢抵抗血管に㧧ける肥厚 化の進展—心拍出量増加の消失, 拈よび, 末梢 血管抵抗増加による血圧上昇」といら発症過程を 想定する．この仮説によれば，昇圧テストによっ て見出される血圧反応性の充進は，特定な人格特 性を有する個人の示す $\beta$ アドレナリン作動性の交 
感神経活動六進が，こうした技法を通じてあらわ にされた状況に他ならない。したがって, 予測因 子としての血圧反応性の充進は否定しないもの の，これを高血圧発症の前提とするものではな い.この意味では，既述の諸仮説と異質なもので ある。また，一定の人格特性こそが将来の高血圧 発症に深くかかわると見なす作業仮説は，その入 り口からして検証が難しく，さまざまな議論を呼 ぶものである。しかし，心理生理学的な興味を強 く引くことから，ここに並べて挙げて扔いた。

最後に, 以上に述べたよらな高血圧の発症過程 に関する作業仮説をめぐっては， $\alpha \beta$ 型の昇圧エ ピソードないしその実験室的模擬である $\alpha \beta$ 型の 昇圧テスト，抢よび，その背後にある $\beta$ アドレナ リン作動性の交感神経活動六進が主たる関心事で あり続けてきた。しかし, 最近の知見によれば, 高血圧家族歴を有する若年成人などの高血圧危険 群にあっては， $\alpha \beta$ 型の昇圧テストを負荷したと きでも，末梢血管抵抗の増加が相対的に優位であ る。つまり， $\alpha$ アドレナリン作動性の交感神経活 動六進が重要な意味を持つという (Ditto \& Miller, 1989; Marrero, Al'Absi, Pincomb, \& Lovallo, 1997).こうしたことと関連して，Marrero et al. (1997)によれば, hyperkinetic な境界域高血压で 見出されるといわれる安静時の心拍出量増加, 乙 たがってその背後にあると考えられる $\beta$ アドレナ リン作動性の交感神経活動方進は，侵襲的技法に よって心拍出量を測定したために生じた Cannon 流の緊急反応を誤って評価したためであるかも知 れないという。ささらに, Carroll, Cross, \& Harris (1990)によれば， $\alpha \beta$ 型の昇圧テストを負荷され た被験者は, 最初のらちは心拍出量増加を来すも のの, 数分間の負荷を経験するらちにしばしば末 梢血管抵抗増加へ移行するようになるともいら． 既述の Folkow (1978)の作業仮説にしても，その 力点の置き所は終始一貫して末梢血管側のはずで あった。これらを総合的に勘案するなら， でなく $\alpha$ アドレナリン作動性の交感神経活動六進 にも焦点を当てた, 高血圧発症の新たな作業仮説 が作られてよいであろら。

\section{今後へ向けて}

以上の議論を基に, 界圧テストの信頼性および 妥当性といら視点から反応性仮説を総合的に評価 するなら, その主張にある程度の有望性は感じさ せるものの, 説得力のある内容とは言えないこと が明らかであろら．実際，血圧反応性など持ち出 さなくても，たとえばベースライン血圧水準や高 血圧家族歴々れ自体が，将来の高血圧発症に対す る予測因子ないし寄与因子としていっそう強力で あるように見えるのである。

Pickering \& Gerin (1990)によれば, 反応性仮説 には二つの根本的な限界がある。すなわち，環境 要因と比べて個体要因を強調し過ぎる。また,一 過性の血圧変化を強調し過ぎるという，確かに， 後者に関しては，一過性の血圧変化から将来の高 血圧が見通せるなら大変魅力的であり，反応性仮 説とかかわる研究数を急膨張させてきた大きな駆 動因であったに違いない。しかし，長い年月をか けて発症する高血圧について, 数分間の昇圧テス トで得られた血圧反応性から予測しよらとするの は，少なからず無理があるように思われる。まし て, 高血圧への寄与となると, 発症過程に血圧反 応性を取り込んだ作業仮説は作れても，かなりの 部分で実験的根拠に乏しく，推測の域を出ないの が現状である。

一方，個体要因を強調し過ぎる点については， 日常生活に拉ける昇圧エピソードあるいはその実 験室的模擬である昇圧テストの型や強度, ないし 持続が問題なのか（環境要因, Fig. 1参照), それ ともこれらに対する血圧反応性の充進が問題なの か（個体要因）を，今一度問い直す必要がある。 たとえば, Anderson, Kearns, \& Belter (1983) は， $\alpha \beta$ 型の昇圧テストである電撃回避訓練をイ 又に課し，また，塩分静注を実施したが，いずれ か一方では慢性的な血圧上昇を作り出せなかっ た、しかし，両方を重ねることでこれに成功して いる。これらのイスは，普段から血圧反応性の高 い特別な一群ではなかったから, 環境要因として のストレス刺激が効いた例といえる，ただし，塩 分摂取と組み合わさったときにのみ，その効果が 発揮されている点は注意すべきである。つまり， Anderson et al. (1983)の知見は, 特別な個体要因 
を前提としなくても高血圧が発症し得ることを示 しているが, 同時に, 行動的要因だけではこれが 生じにくいことも示唆している.もっとも, 彼ら のイヌがヒトでの高血圧と類似な症状を呈してい たかは，いささか疑問であるとされる (Light, 1992).むしろ, 高血圧の症状といら点でヒトとの 類似性が高いのは自然高血圧発症ラットであるが (Trippodo \& Frohlich, 1981), この場合は高血圧の 発症以前から昇圧テストに対する血圧反応性の充 進を認める (Hallback \& Folkow, 1974).こうし て, 個体要因の重要性はあながち無視できないこ とが再確認される。

いずれにしろ, 反応性仮説の内容はいささか単 純過ざるようである。体質遺伝を基盤とし，これ に年齢や人種・性別などの生物的要因, 食事・睡 眠・運動などといった生活習慣，そしてストレス (これを呼び込みやすいA型行動パターンのよう な人格・行動特性も含めた）といら 4 種の遠因が 複合的に効いて, 高血圧は結実するのであろら．

(Fig. 1 では，これらの要因が別の視点から整理 され，組み込まれている。）もしそらだとすれば, 環境要因を強調するのであれ，個体要因に重きを 置くのであれ，これら 4 種の遠因を総合的に取り 込みながら高血圧発症の作業仮説を描く必要があ る.上述の Anderson et al. (1983)の知見は，その 意味できわめて示唆に富むものであり, また, 本 評論では取り上げなかったが, Lovallo \& Wilson （1992）の腎機能と血圧反応性の相互作用を扱った 高血圧発症に関する作業仮説も興味深いものであ る.こうした, 各種の要因を複合的に取り込んだ 統合的作業仮説の構築は, 高血圧に限らず，いわ ゆる生活習慣病の発症過程を理解する上で大いに 有効性を発揮するものと成り得よう.

最後に, 血圧反応性の研究は, 当然ながら血行 力学的接近法を主とするが, このやり方が別種の 限界を作り出すと思われる. 実際, Julius \& Egan (1986)によれば，高血圧がいかなる血行動態を有 するか，また，その背景を成す機序がいかなるも のかといったあたりの解明は，すでに十分な段階 に達しているか，または現在進行中である。しか し，何故こうしたことが生じるのかといった病因 論となると, 血行動態を検討するだけでは解明が
難しいという。たとえば, 細胞膜イオン輸送系 や，ストレスが作用する遺伝形質の問題などに力 点が置かれるべきなのであろう．血圧反応性に限 らず, 今後の血行力学的接近法は, こうした最新 のアプローチに支えられながら進むものと期待さ れる。

\section{文献}

Abboud, F. M. 1982 The sympathetic system in hypertension. Hypertension, 4 (suppl II), II-208-II225.

Allen, M. T., Boquet, A. J., \& Shelley, K. S. 1991 Cluster analyses of cardiovascular responsivity to three laboratory stressors. Psychosomatic Medicine, 53, 272-288.

Allen, M. T., \& Crowell, M. D. 1989 Patterns of autonomic response during laboratory stressors. Psychophysiology, 26, 603-615.

Anderson, D., Kearns, W., \& Belter, W. 1983 Progressive hypertension in dogs by avoidance conditioning and saline infusion. Hypertension, 5, 286-291.

Borghi, C., Costa, F. V., Boschi, S., Mussi, A., \& Ambrosioni, E. 1986 Predictors of stable hypertension in young borderline subjects: A five-year follow-up study. Journal of Cardiovascular Pharmacology, 8 (Suppl. 5), S138-S141.

Carroll, D., Cross, G., \& Harris, M. G. 1990 Physiological activity during a prolonged mental stress task: evidence for a shift in the control of pressor reactions. Journal of Psychophysiology, 4, 261-269.

Ditto, B., \& Miller, S. B. 1989 Forearm blood flow responses of offspring of hypertensives to an extended stress task. Hypertension, 13, 181-187.

Falkner, B., Kushner, H., Onesti, G., \& Angelakos, E. T. 1981 Cardiovascular characteristics in adolescents who develop essential hypertension. Hypertension, 3, 521-527.

Folkow, B. 1978 Cardiovascular structural adaptation: its role in the initiation and maintenance of primary hypertension. Clinical Science and Molecular Medicine, 55, 3s-22s.

Folkow, B. 1987 Psychosocial and central nervous influences in primary hypertension. Circulation, 76 (suppl I), I-10-I-19.

Gellman, M., Spitzer, S., Ironson, G., Llabre, M., Saab, P., Pasin, R., Weidler, D., \& Schneiderman, N. 1990 Posture, place and mood effects on ambulatory monitoring. Psychophysiology, 27, 541-555.

Gramer, M., \& Huber, H. P. 1993 Temporal and across-task stability of cardiovascular response patterns during psychological and physical chal- 
lenge. Homeostasis, 34, 289-301.

Gringnolo, A., Koepke, J. P., \& Obrist, P. A. 1982 Renal function, heart rate, and blood pressure during exercise and avoidance in dogs. American Journal of Physiology, 242, R482-R490.

Guyton, A. C. 1980 Circulatory Physiology III. Arterial pressure and hypertension. Philadelphia: W. B. Saunders.

Hallback, M., \& Folkow, B. 1974 Cardiovascular responses to acute mental "stress" in spontaneously hypertensive rats. Acta Physiological Scandinavica, 90, 684-698.

Johnston, D. W., Anastasiades, P., Vögele, C., Clark, D. M., Kitson, C., \& Steptoe, A. 1992 The relationship between cardiovascular responses in the laboratory and in the field: The importance of "active coping." In T. F. H. Schmidt, B. T. Engel, \& G. Blümchen (Eds.) Temporal variations of the cardiovascular system. Berlin: Springer-Verlag, Pp.127-144.

Julius, S., \& Egan, B. 1986 Hemodynamics of hypertension. In A. Zanchetti, \& R. C. Tarazi (Eds.) Handbook of Hypertension. Vol.7: Pathophysiology of hypertension. Amsterdam: Elsevier, Pp.153-178.

Julius, S., Pascual, A. V., \& London, R. 1971 Role of parasympathetic inhibition in the hyperkinetic type of borderline hypertension. Circulation, 44, 413-418.

Julius, S., \& Schork, M. A. 1978 Predictors of hypertension. Annals of the New York Academy of Sciences, 304, 38-52.

Julius, S., Weder, A. B., \& Egan, B. M. 1983 Pathophysiology of early hypertension: Implication for epidemiologic research. In F. Gross, \& $T$. Strasser (Eds.) Mild hypertension: Recent advances. New York: Raven Press, Pp.219-236.

Kamarck, T. W., Jennings, J. R., \& Manuck, S. B. 1993 Psychometric applications in the assessment of cardiovascular reactivity. Homeostasis, 34, 229243.

Kamarck, T. W., Jennings, J. R., Geile, M., \& Manuck, S. B. 1994 A multidimentional measurement model for cardiovascular reactivity: Stability and cross-validation in two adult samples. Health Psychology, 13, 471-478.

Light, K. C. 1992 Differential responses to salt intake-stress interactions: Relevance to hypertension. In Turner, J. R., Sherwood, A., \& Light, K. C. (Eds.) Individual differences in cardiovascular response to stress. New York: Plenum Press, Pp.245-263.

Light, K. C., Koepke, J. P., Obrist, P. A., \& Willis, P. W. 1983 Psychological stress induces sodium and fluid retention in men at high risk for hypertension. Science, 220, 429-431.
Lovallo, W. R., \& Wilson, M. F. 1992 A biobehavioral model of hypertension development. In J. R. Turner, A. Sherwood, \& K. C. Light (Eds.) Individual differences in cardiovascular response to stress. New York: Plenum Press, Pp.265-280.

Lund-Johansen, P. 1983 Hemodynamic alterations in early essential hypertension: Recent advances. In F. Gross, \& T. Strasser (Eds.) Mild hypertension: Recent advances. New York: Raven Press, Pp.237249.

Manuck, S. B., Kamarck, T. W., Kasprowicz, A. S., \& Waldstein, S. R. 1993 Stability and patterning of behaviorally evoked cardiovascular reactivity. In J. Blascovich, \& E. S. Katkin (Eds.) Cardiovascular reactivity to psychological stress and disease. Washigton: American Psychological Association, Pp.111-134.

Manuck, S. B., Kasprowicz, A. L., \& Muldoon, M. F. 1990 Behaviorally-evoked cardiovascular reactivity and hypertension: Conceptual issues and potential associations. Annals of Behavioral Medicine, 12, 17-29.

Marrero, A. F., Al'Absi, M., Pincomb, G. A., \& Lovallo, W. R. 1997 Men at risk for hypertension show elevated vascular resistance at rest and during mental stress. International Journal of Psychophysiology, 25, 185-192.

Matthews, K. A. 1986 Summary, conclusions, and implications. In K. A. Matthews, S. M. Weiss, T. Detre, T. M. Dembroski, B. Falkner, S. B. Manuck, \& R. B. Williams, (Eds.) Handbook of stress, reactivity, and cardiovascular disease. New York: John Wiley \& Sons, Pp.461-473.

Muldoon, M. F., Terrell, D. F., Bunker, C. H., \& Manuck, S. B. 1993 Family history studies in hypertension research: Review of the literature. American Journal of Hypertension, 6, 76-88.

Obrist, P. A. 1983 Beta-adrenergic hyperresponsivity to behavioral challenges: A possible hypertensive risk factor. In J. F. Orlebeke, G. Mulder, \& L. J. P. van Doornen (Eds.) Psychophysiology of cardiovascular control. New York: Plenum Press, Pp.667682.

Obrist, P. A., Gaebelin, C. J., Teller, E., Langer, A. W., Gringnolo, A., Light, K. C., \& McCubbin, J. A. 1978 The relationship between heart rate, carotid $\mathrm{dP} / \mathrm{dt}$, and blood pressure in humans as a function of the type of stress. Psychophysiology, 15, 102-115.

Pickering, T. G., \& Gerin, W. 1990 Cardiovascular reactivity in the laboratory and the role of behavioral factors in hypertension: A critical review. Annals of Behavioral Medicine, 12, 3-16.

Pickering, T. G., \& Gerin, W. 1992 Does cardiovascular reactivity have pathogenic significance in hypertensive patients? In E. H. Johnson, W. D. 
Gentry, \& S. Julius (Eds.) Personality, elevated blood pressure, and essential hypertension. Washington: Hemisphere Publishing Corporation, Pp.151-173.

Saab, P. G., \& Schneiderman, N. 1993 Biobehavioral stressors, laboratory investigation, and the risk of hypertension. In J. Blascovich, \& E. S. Katkin (Eds.) Cardiovascular reactivity to psychological stress and disease. Washington: American Psychological Association, Pp.49-82.

澤田幸展 1990 血圧反応性一仮説群の構築とその評 価一心理学評論, 33, 209-238.

Sawada, Y. 1993 Reproducible increases in blood pressure during intermittent noise exposure: underlying haemodynamic mechanisms specific to passive coping. European Journal of Applied Physiology, 67, 367-374.

澤田幸展 血行力学的反応 宮田 洋監修 新生理心 理学 第 1 巻 生理心理学の基礎 第 10 章 北大路 書房 印刷中.

澤田幸展・山越憲一 1995 実験室および日常生活に 扣ける循環動態調節の関連性 第10回生体・生理工 学シンポジウム論文集, Pp.165-168.

Sanchez, A., Pedraja, M.J., Quiñones, E., \& Martinez, F. 1996 A historic-quantitative approach to psychophysiological research: The first three decades of the journal Psychophysiology (19641993). Psychophysiology, 33, 629-636.

Sherwood, A., \& Turner, J. R. 1992 A conceptual and methodological overview of cardiovascular reactivity research. In J. R. Turner, A. Sherwood, \& K. C. Light (Eds.) Individual differences in cardiovascular response to stress. New York:
Plenum Press, Pp.3-32.

Sherwood, A., \& Turner, J. R. 1993 Postural stability of hemodynamic responses during mental challenge. Psychophysiology, 30, 237-244.

Stamler, R., Stamler, J., Riedlinger, W. F., Algera, G., \& Roberts, R. H. 1979 Family (parental) history and prevalence of hypertension. Journal of the American Medical Association, 241, 43-46.

Thomas, C. B., \& Duszynski, K. R. 1982 Blood pressure levels in young adulthood as predictors of hypertension and the fate of the cold pressor test. The Johns Hopkins Medical Journal, 151, 93-100.

Trippodo, N. C., \& Frohlich, E. D. 1981 Similarities of genetic (spontaneous) hypertension: Man and rat. Circulation Research, 48, 309-319.

Turner, J. R., \& Sherwood, A. 1991 Postural effects on blood pressure reactivity: Implications for studies of laboratory-field generalization. Journal of Psychosomatic Research, 35, 289-295.

Turner, J. R., Sherwood, A., \& Light, K. C. 1990 Generalization of cardiovascular response: supportive evidence for the reactivity hypothesis. International Journal of Psychophysiology, 11, 207-212.

Turner, J. R., Ward, M. M., Gellman, M. D., Johnston, D. W., Light, K. C., \& van Doornen, L. J. P. 1994 The relationship between laboratory and ambulatory cardiovascular activity: Current evidence and future directions. Annals of Behavioral Medicine, 16, 12-23.

van Doornen, L. J. P., \& van Blokland, R. W. 1992 The relationship between cardiovascular and catecholamine reactions to laboratory and real-life stress. Psychophysiology, 29, 173-181. 